
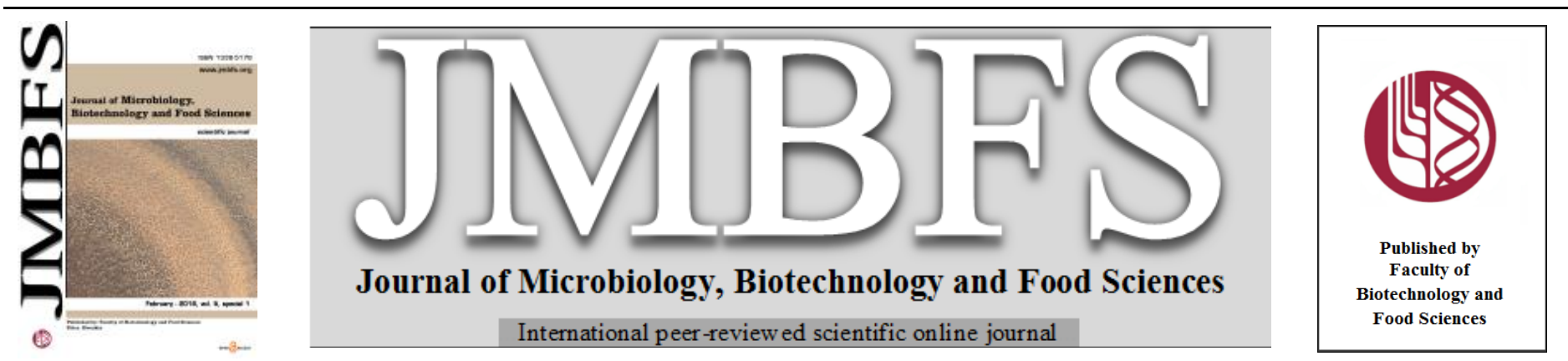

\title{
IMPACT OF TILMICOSIN ON THE RABBIT SPERMATOZOA MOTILITY AND VIABILITY
}

\author{
Tomáš Slanina $*^{l}$, Renáta Kováčová ${ }^{2}$, Norbert Lukáč ${ }^{l}$, Peter Massányi ${ }^{l}$
}

Address(es): MSc. Tomáš Slanina, PhD.

${ }^{1}$ Slovak University of Agriculture in Nitra, Faculty of Biotechnology and Food Sciences, Department of Animal Physiology, Tr. A. Hlinku 2, 94976 Nitra, Slovak Republic, phone number: +421 376414111 .

${ }^{2}$ Institute for State Control of Veterinary Biologicals and Medicaments, Biovetská 34, 94901 Nitra, Slovak Republic.

*Corresponding author: tomas.slanina@uniag.sk

doi: 10.15414/jmbfs.2016.5.special1.53-56

\section{ARTICLE INFO}

Received 9. 12. 2015

Revised 14. 1.2016

Accepted 20. 1.2016

Published 8. 2. 2016

Regular article

open 2 ACCESS

\begin{abstract}
The aim of this study was to examine the effects of tilmicosin on rabbit spermatozoa viability and motility parameters during short-term in vitro incubation at $37^{\circ} \mathrm{C}$. Semen samples were collected from adult New Zealand White rabbits and diluted with eight concentrations of tilmicosin: 0.300, 0.350, 0.400, 0.466, 0.500, 0.583, 0.600 and $0.700 \mathrm{mg} \cdot \mathrm{ml}^{-1}$ (TIL $1-8$ ) diluted in the physiological solution. The

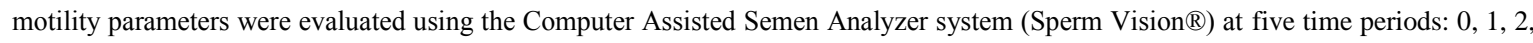
3 and 4 hours. Cell viability was measured using the metabolic activity MTT assay. Immediately at the beginning of incubation significantly higher values of motility (MOT) and progressive motility (PRO) were detected in samples TIL2, TIL5 and TIL7 compared to the control. Significantly lower values of tested motility parameters were observed after 1 and 3 hours of incubation. All concentrations of tilmicosin have no significantly negative effect on the parameters of the MOT, PRO and velocity curved line (VCL) after 4 hours of incubation in vitro at $37^{\circ} \mathrm{C}$. Concentration of tilmicosin $0.350 \mathrm{mg} \cdot \mathrm{ml}^{-1}$ has a positive impact on MOT $(72.39 \pm 15.62 \%$, $\mathrm{p}<0.001)$ and PRO $(54.28 \pm 21.23 \%, \mathrm{p}<0.01)$ of rabbit spermatozoa after 4 hours of incubation in vitro at $37^{\circ} \mathrm{C}$. Supplementation of tilmicosin led to preservation of the cell over all time periods of the in vitro incubation. The results indicate that tilmicosin could be used to semen extenders without negative effects on rabbit spermatozoa motility and viability.
\end{abstract}

\section{INTRODUCTION}

Antimicrobial agents are of extraordinary importance for the control of bacterial growth in liquid-preserved ejaculates of farm animals. To counteract increasing bacterial resistance to conventional antibiotics, novel agents with different active mechanisms have to be developed (Schulze, et al., 2016). The bacterial presence in semen samples could be especially problematic in situations where the ejaculates are used for artificial insemination $24 \mathrm{~h}$ or more after collection (Suarez and Pacey, 2006). Therefore, it is of great importance that the extended shipped ejaculates maintain the highest quality upon arrival. Bacterial contamination is routinely observed in raw, extended and stored semen produced for artificial insemination when semen is collected by the gloved-hand technique A study reported that $62.5 \%$ of raw ejaculates and $79 \%$ of extended boar semen doses showed bacterial contamination (Maroto Martín et al., 2010). The incidence of bacterial presence in the germ line can impact semen quality, also affecting the DNA molecule (Gonzalez-Marin, et al., 2012). The inclusion of antibiotics in semen extenders is recommended for the control of several microorganisms that can be present in spermatozoa (Bielansky, 2007; Thibier and Guerin, 2000) and The World Organization for Animal Health recommends the inclusion of antibiotics in extenders used in cryopreservation of spermatozoa, in order to control bacterial contamination (Madeira, et al., 2014).

Tilmicosin, 20-deoxo-20-(3.5-dimethylpiperidin-1-yl) desmycosin, is a semisynthetic derivative of tylosin (Giguere, et al., 2013). Tilmicosin is a macrolide antibiotic developed for veterinary use. It is recommended for treatment and prevention of respiratory diseases in cattle, sheep, pigs, rabbits, chickens and turkeys and for the treatment of other diseases caused by tilmicosinsensitive microorganisms (WHO Technical Report Series, 2009). Tilmicosin is a narrow spectrum antibiotic and effective against Gram-positive pathogens (Hogeveen, 2005), although some gram-negative bacteria are affected and the drug reportedly has some activity against mycoplasma. Preliminary studies have shown that $95 \%$ of studied isolates of Pasturella haemolytica are sensitive (Plamb, 2008).

Antibiotics are necessary and mandatory additives in semen extenders for the liquid preservation of several animal species (Bryła and Trzcińska, 2015) Although opportunistic contaminants of semen generally do not incur an important health risk for the inseminated females, they can affect spermatozoa quality (Yániz et al., 2010). Fertilizing capacity of spermatozoa can be directly affected by bacteria (Morrell 2006) that can impair the spermatoza motility, have the ability to adhere with spermatozoa, and can induce the acrosome reaction (Qadeer, et al., 2013)

The objective of our study was to examine the effects of tilmicosin, macrolide antibiotic, on rabbit spermatozoa viability and motility parameters in vitro.

\section{MATERIAL AND METHODS}

\section{Biological material}

In this study the ejaculates were collected from adult New Zealand White rabbits using artificial vagina (Massányi et al., 2008). The rabbit were kept in individual cages and fed ad libitum with a commercial diet.

\section{Sample preparation}

Semen was diluted in a ratio of 1 part of semen and 6 parts of physiologica solution (Sodium chloride 0.9\% Braun, B. Braun Melsungen AG, Melsungen, Germany) - control groups (TILC). At the same ratio semen was diluted with eight different concentrations of tilmicosin (purity 94\%, Sigma-Aldrich, St. Louis, USA) solution: TIL1 - $0.300 \mathrm{mg} \cdot \mathrm{ml}^{-1}$; TIL2 $-0.350 \mathrm{mg} \cdot \mathrm{ml}^{-1}$; TIL3 $0.400 \mathrm{mg} \cdot \mathrm{ml}^{-1}$; TIL4 - $0.466 \mathrm{mg} \cdot \mathrm{ml}^{-1}$; TIL5 - $0.500 \mathrm{mg} \cdot \mathrm{ml}^{-1}$; TIL6 - 0.583 mg.ml ${ }^{-1}$; TIL7 - $0.600 \mathrm{mg} \cdot \mathrm{ml}^{-1}$; TIL8 - $0.700 \mathrm{mg} \cdot \mathrm{ml}^{-1}$ diluted in the physiological solution. All samples were cultured at $37^{\circ} \mathrm{C}$ and measured at five time periods: $0,1,2,3$ and 4 hours (Time $0-4$ ). The experiment was realized in 6 replicates.

\section{Analytical method}

Each of thus prepared samples was evaluated using a Computer Assisted Semen Analyzer (CASA) system - Sperm Vision ${ }^{\circledR}$ (Minitub, Tiefenbach, Germany) equipped with a microscope (Olympus BX 51, Japan) to assess the spermatozoa motility. Each sample was placed into Makler Counting Chamber®) (depth 10 
$\mu \mathrm{m}$, Sefi-Medical Instruments, Germany). In the present study the following parameters were evaluated - total motile spermatozoa (MOT) [\%], progressively motile spermatozoa (PRO) [\%] and velocity curved line (VCL) $\left[\mu \mathrm{m} . \mathrm{s}^{-1}\right]$. Within each of the measurement by the CASA system were evaluated motility parameters from minimum seven fields of Makler Counting Chamber.

Viability of rabbit spermatozoa exposed to tilmicosin in vitro was evaluated by the metabolic activity (MTT) assay (Tvrdá et al., 2015). This colorimetric assay measures the conversion of 3-(4.5-dimetylthiazol-2-yl)-2.5-diphenyltetrazolium bromide (MTT; Sigma-Aldrich, St. Louis, USA) to purple formazan particles by mitochondrial succinate dehydrogenase of intact mitochondria of living cells. Formazan was measured spectrophotometrically by a microplate ELISA reader (Multiskan FC, ThermoFisher Scientific, Finland). The data are expressed in percentage of control (i.e. optical density of formazan from cells not exposed tilmicosin). Viability of the spermatozoa was tested in the samples TIL1, TIL2 and TIL8. Results from the analysis were collected during four repeated experiments for each concentration.

\section{Statistical analysis}

Obtained data were statistically analysed by PC program Excel and a statistics package GraphPad Prism 5 (GraphPad Software, Inc. La Jolla, California, USA) using one-way ANOVA with Dennett's posttest. Statistical significance was indicated by $p$ values of less than $0.05 ; 0.01$ and 0.001 .

\section{RESULTS AND DISCUSSION}

The results of CASA analysis of selected motility parameters are presented in Figures 1-3. At the beginning of incubation significantly higher percentage of spermatozoa motility was detected in the samples TIL3 $(\mathrm{p}<0.05)$, TIL5 $(\mathrm{p}<0.01)$ and TIL7 $(\mathrm{p}<0.001)$ compared to control (TIL K). At the same time nonsignificant differences were observed in the others experimental samples at the Time 0 . However after 1 hour of incubation negative effect of tilmicosin on the turkey spermatozoa motility was detected in the samples TIL3, TIL5, TIL6, TIL7 and TIL 8 in comparison to the control. With increasing time of incubation between tested samples and control similar values of motility were observed. Significantly $(\mathrm{p}<0.001)$ protective effect of tilmicosin on preservation of spermatozoa motility was found in the samples TIL2 $\left(0.350 \mathrm{mg} \cdot \mathrm{ml}^{-1}\right)$. After 4 hours of incubation percentage of motility was $72.69 \%$ in the sample TIL2 and $46.10 \%$ in the control sample (Figure 1).

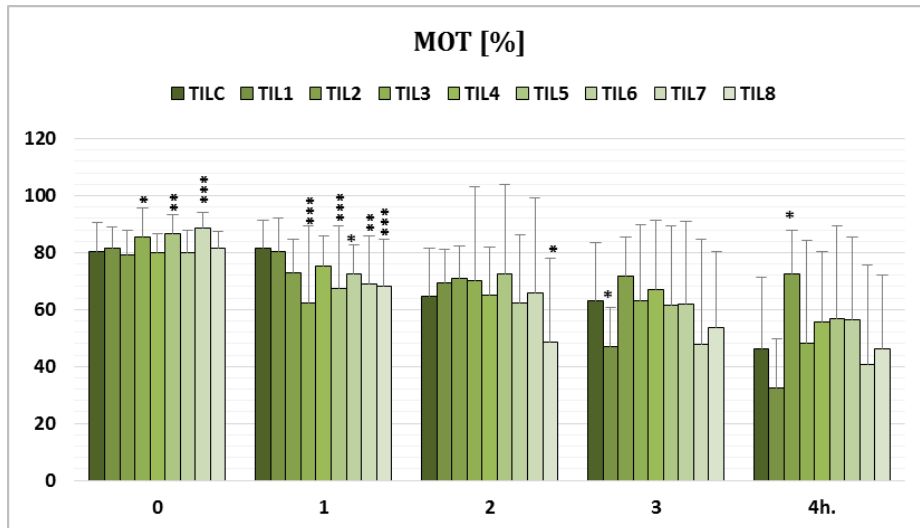

Figure 1 Spermatozoa motility (in \%) after tilmicosin addition. TILC - contro sample and TIL $1-8$ (in this order): $0,300 \mathrm{mg} \cdot \mathrm{ml}^{-1} ; 0,350 \mathrm{mg} \cdot \mathrm{ml}^{-1} ; 0,400 \mathrm{mg} \cdot \mathrm{ml}^{-}$ ${ }^{1} ; 0,466 \mathrm{mg} \cdot \mathrm{ml}^{-1} ; 0,500 \mathrm{mg} \cdot \mathrm{ml}^{-1} ; 0,583 \mathrm{mg} \cdot \mathrm{ml}^{-1} ; ; 0,600 \mathrm{mg} \cdot \mathrm{ml}^{-1} ; 0,700 \mathrm{mg} \cdot \mathrm{ml}^{-1}$ Significant differences $* p<0.05 ; * * p<0.01 ; * * * p<0.001$.

Spermatozoa progressive motility (PRO) followed the tendency of spermatozoa motility. Measurement of progressive spermatozoa motility (PRO) showed statistically significant difference immediately at the beginning of incubation (Figure 2). The values of samples TIL3 (76.78\%; p <0.05), TIL5 $(78.43 \%$; $\mathrm{p}<0.01)$ and TIL7 $(81.19 \%$; $\mathrm{p}<0.001)$ were significantly higher in comparison to the control sample TILK $(66.12 \%)$. After 2 hours of in vitro incubation significant decrease of progressive motility was detected in all tested samples excepr sample TIL1 with the lowest concentration of tilmicosin $\left(0.300 \mathrm{mg} \cdot \mathrm{ml}^{-1}\right)$. With increasing time of incubation values of progressive motility between tested samples and control were balanced. Significantly higher $(p<0.001)$ progressive motility was observed only in the sample TIL7 at the Time 4 .

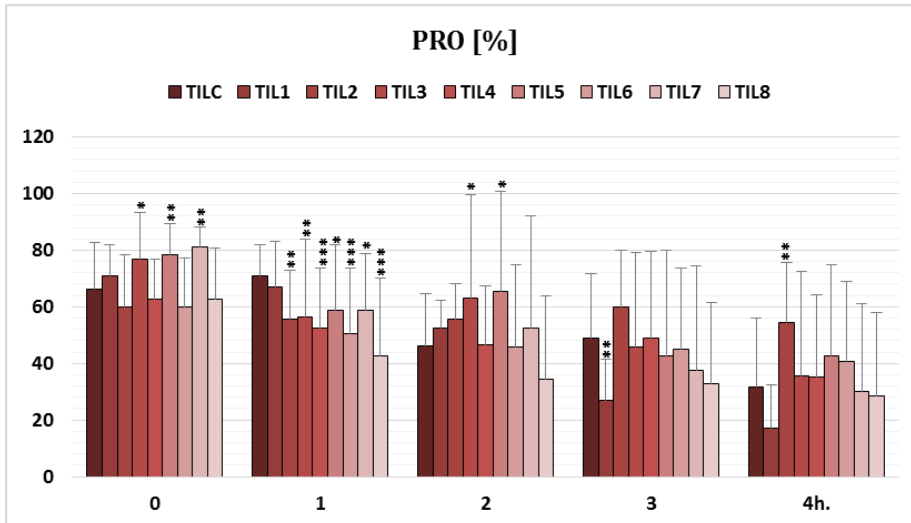

Figure 2 Spermatozoa progressive motility (in \%) after tilmicosin addition. TILC - control sample and TIL 1 - 8 (in this order): $0,300 \mathrm{mg} \cdot \mathrm{ml}^{-1} ; 0,350 \mathrm{mg} \cdot \mathrm{ml}^{-1}$, $0,400 \mathrm{mg} \cdot \mathrm{ml}^{-1} ; 0,466 \mathrm{mg} \cdot \mathrm{ml}^{-1} ; 0,500 \mathrm{mg} \cdot \mathrm{ml}^{-1} ; 0,583 \mathrm{mg} \cdot \mathrm{ml}^{-1}$.; $0,600 \mathrm{mg} \cdot \mathrm{ml}^{-1}$; $0,700 \mathrm{mg} \cdot \mathrm{ml}^{-1}$. Significant differences ${ }^{*} p<0.05 ; * * p<0.01 ; * * * p<0.001$

The initial analysis of velocity curved line (VCL) proved significantly higher values in samples TIL2, TIL5 and TIL7 ( $<<0.001)$ compared to the contro sample TILK. Significantly lower values of VCL were detected in samples TIL2, TIL 4 - TIL8 in comparison to the control at the Time 1 and 3 (Figure 3.). At the other time of in vitro incubation balanced values of VCL were detected between tested samples and control group.

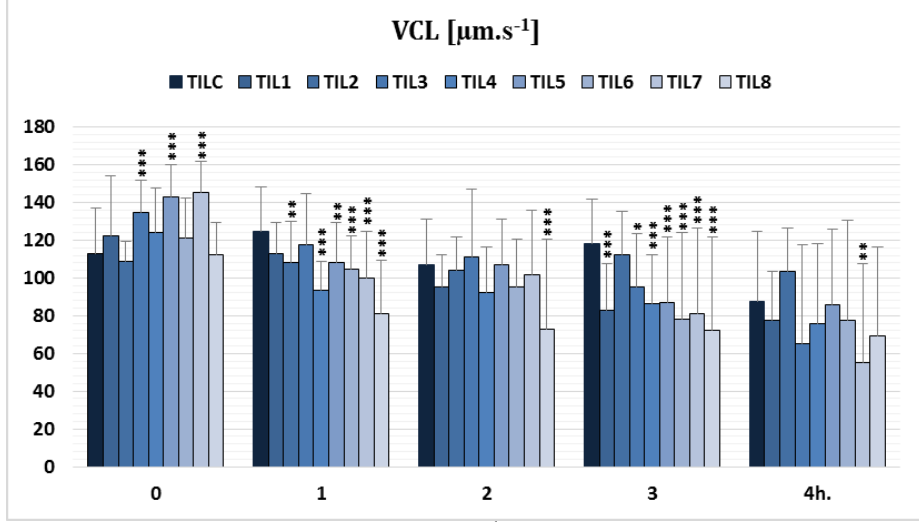

Figure 3 Velocity curved line (in $\mu \mathrm{m} . \mathrm{s}^{-1}$ ) after tilmicosin sulphate. TILC -

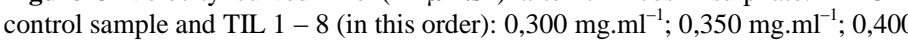
mg.ml $l^{-1} ; 0,466 \mathrm{mg} \cdot \mathrm{ml}^{-1} ; 0,500 \mathrm{mg} \cdot \mathrm{ml}^{-1} ; 0,583 \mathrm{mg} \cdot \mathrm{ml}^{-1} ; 0,600 \mathrm{mg} \cdot \mathrm{ml}^{-1} ; 0,700$ mg.ml ${ }^{-1}$. Significant differences $* p<0.05 ; * * p<0.01 ; * * * p<0.001$

The impact of tilmicosin on viability of rabbit spermatozoa was measured in the samples TIL1 - $0.300 \mathrm{mg} \cdot \mathrm{ml}^{-1}$, TIL2 - $0.350 \mathrm{mg} \cdot \mathrm{ml}^{-1}$ and TIL3 $-0.700 \mathrm{mg} \cdot \mathrm{ml}^{-1}$. During the whole in vitro incubation the sample TIL 2 showed the most positive effect on the all monitored spermatozoa motility parameters. According to the MTT assay, significantly decrease of viability was not detected. Nevertheless at the Time 2 increasing of percentage of vital cells was observed (Figure 4) Similar to the CASA analysis, the MTT test revealed stimulation in the cell viability in the samples TIL1 and TIL2. The sample TIL1 (183.3\%) showed significantly higher $(\mathrm{p}<0.05)$ values of viability in comparison to the control sample at the Time 2 and sample TIL2 at Time 4 .

\section{MTT [\%]}

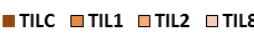

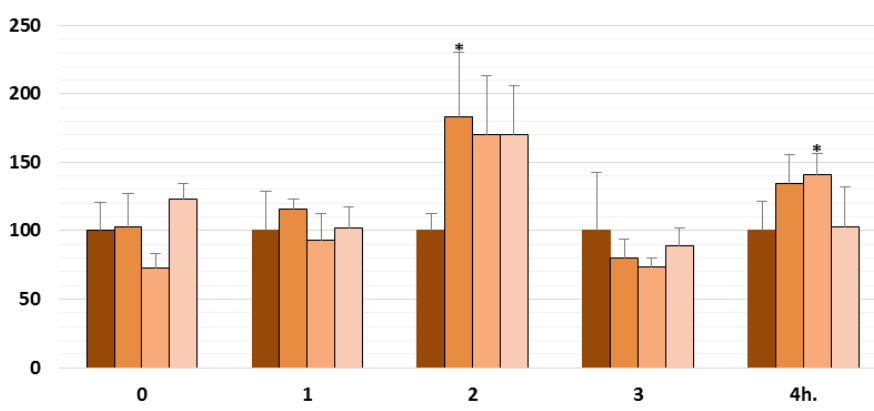

Figure 4 The effect of various doses of tilmicosin on the viability of rabbit spermatozoa. TILC - Control sample, TIL1 - $0.300 \mathrm{mg}^{-\mathrm{ml}^{-1}}$, TIL2 - 0.350 mg.ml ${ }^{-1}$ and TIL3 $-0.700 \mathrm{mg} \cdot \mathrm{ml}^{-1}$. 
The effect of bacteria on spermatozoa quality is still controversial. Semen is an ideal medium for the establishment and growth of several microorganisms including bacteria (Bryla and Trzcińska, 2015). Microbial contamination reduces spermatozoa motility, shortens the storage time of viable semen, and decreases fertility rates, resulting in economic losses for AI facilities (Bussalleu et al., 2011). In contrast, some researchers have found that the presence of bacterial strains in semen samples does not usually impair semen quality (Cottell et al., 2000) and that the bacterial contamination of the ejaculate has no significant effect on the farrowing rate or the total number of piglets born (Reicks and Levis, 2008). Therefore it is very important to test not only the effect of bacterial strains on semen quality parameters of in vitro conditions but also testing the impact of the commercially used antibiotics.

Several studies have considered the effect of different antibiotics on the quality of stored semen. The data reported in study of Gloria et al. (2014) reveals that combinations of oflexacin (10-400 mg.ml $\left.{ }^{-1}\right)$ and tylosin (10-250 mg.ml $\left.{ }^{-1}\right)$, seems to have a negligible effect on spermatozoa motility $(p>0.05)$. Furthermore, progressive motility was significantly higher for spermatozoa diluted with both antibiotic combinations compared with samples without antibiotics $(\mathrm{p}<0.01)$. Our results agree with Gloria et al. (2014) and confirmed that lower concentration of macrolide antibiotics, in our study tilmicosin, have no negative effect on spermatozoa motility. Madeira et al. (2014) showed that the combination of antibiotics (PES $=100,000 \mathrm{IU} / \mathrm{ml}$ penicillin and $0.100 \mathrm{mg} \cdot \mathrm{ml}^{-1}$ streptomycin GTLS: 0.500 mg. $\mathrm{ml}^{-1}$ gentamicin; $0.100 \mathrm{mg} \cdot \mathrm{ml}^{-1}$ tylosin; $0.300 \mathrm{mg} \cdot \mathrm{ml}^{-1}$ lincomycin and $0.600 \mathrm{mg} \cdot \mathrm{ml}^{-1}$ spectinomycin; CEF: $0.50 \mathrm{mg} \cdot \mathrm{ml}^{-1}$ ceftiofur sodium; ENR: $0.001 \mathrm{mg} \cdot \mathrm{ml}^{-1}$ enrofloxacin) in extenders at the tested concentrations did not influence the integrity of either spermatozoa membrane or acrosome, in both cooled and thawed ram spermatozoa. Nevertheless, spermatozoa motility was negatively affected with antibiotic addition. The reduction in spermatozoa motility may be attributed to the reduction of mitochondrial activity in spermatozoa, since quinolone antibiotics inhibit DNA gyrase (Sárközy, 2001). This particular mechanism of action allows the elimination of strains resistant to antibiotics which act on the cell wall, the cytoplasmic membrane or on protein synthesis. Qadeer et al. (2013) suggested that neomycin, polymyxin, or colistin in combination with penicillin did not deteriorate semen quality and may be suggested to replace streptomycin in traditional antibiotic combination for cryopreservation of Nilli-Ravi buffalo bull spermatozoa. On the other side, combination of gentamycin, tylosin, lincomycin and spectinomycin have slightly significantly $(\mathrm{p}<0.05)$ negative effect on canine total spermatozoa motility (Becher et al., 2013).

The highest difference of toxicity between the cell lines and the spermatozoa were observed after application of the macrolide antibiotic tilmicosin. According to our measurements, the concentration of tilmicosin $0.350 \mathrm{mg} \cdot \mathrm{ml}^{-1}$ has a significantly positive effect on the motility and progressive motility and in the study of VERO cells survival of $25.79 \%$ was detected (Fülöpová et al., 2012) For the BHK-21 cells is the lethal dose a concentrations already $0.050 \mathrm{mg} \cdot \mathrm{ml}^{-1}$. At the concentration of $0.200 \mathrm{mg}^{\mathrm{ml}}{ }^{-1}$ only one third of cells was vital. The MTT assay showed that even the sample with the highest concentration of tilmicosin $\left(0.700 \mathrm{mg} \cdot \mathrm{ml}^{-1}\right)$ had not a negative effect on viability of rabbit spermatozoa. The samples TIL2 $\left(0.350 \mathrm{mg} \cdot \mathrm{ml}^{-1}\right)$ even showed significantly increase $(\mathrm{p}<0.05)$ of percentage of vital spermatozoa at the Time 4, which is in correlation with the results of motility analysis. During whole in vitro incubation no significant differences in this concentration of tilmicosin were detected.

\section{CONCLUSION}

According to our results it may be concluded that tilmicosin, a macrolide antibiotic, in concentrations from 0.300 to $0.700 \mathrm{mg} \cdot \mathrm{ml}^{-1}$ have not significantly negative effect on selected motility parameters after 4 hours of in vitro incubation at $37^{\circ} \mathrm{C}$. Even concentration of tilmicosin $0.350 \mathrm{mg} \cdot \mathrm{ml}^{-1}$ showed significantly positive effect on motility and progressive motility of rabbit spermatozoa. Hereby neither the highest tested concentration of tilmicosin $\left(0.700 \mathrm{mg} \cdot \mathrm{ml}^{-1}\right)$ had negative impact on the mitochondrial metabolic activity. Therefore, we can recommend the use of tilmicosin for rabbit semen extenders.

Acknowledgments: This study was supported by projects VEGA 1/0760/15; 1/0857/14, APVV-0304-12 and KEGA 006/SPU-4/2015. The research leading to these results has received funding from the European Community under project no 26220220180: Building Research Centre "AgroBioTech".

\section{REFERENCES}

BECHER, A. C. - SPERGSER, J. - AURICH, C. - ZOTTLER, E. - AURICH, J E. - SCHÄFER-SOMI, S. (2013). Cooled storage of canine semen: in vitro effects of different concentrations of an antibiotic combination on growth of mollicutes. Reproduction in domestic animals, 48(6), 961-966. http://dx.doi.org/10.1111/rda.12194

BIELANSKI, A. (2007). Disinfection procedures for controlling microorganisms in the semen and embryos of humans and farm animals. Theriogenology, 68(1), 1-22. http://dx.doi.org/10.1016/j.theriogenology.2007.03.025
BRYŁA, M. - TRZCIŃSKA, M. (2015). Quality and fertilizing capacity of boar spermatozoa during liquid storage in extender supplemented with different antibiotics. Animal Reproduction Science, 163(2015), 157-163. http://dx.doi.org/10.1016/j.anireprosci.2015.11.005

BUSSALLEU, E. - YESTE, M. - SEPÚLVEDA, L. - TORNER, E. - PINART, E. - BONET, S. (2011). Effects of different concentrations of enterotoxigenic and verotoxigenic E. coli on boar sperm quality. Animal Reproductive Science, 127(3-4), 176-182. Doi: $\quad$ 10.1016/j.anireprosci.2011.07.018 http://dx.doi.org/10.1016/j.anireprosci.2011.07.018

COTTELL, E. - HARRISON, R. F. - MCCAFFREY, M. - WALSH, T. MALLON, E. - BARRY-KINSELLA, C. (2000). Are seminal fluid microorganisms of significance or merely contaminants? Fertility and Sterility, 74(3), 465-470. http://dx.doi.org/10.1016/s0015-0282(00)00709-3

FÜLÖPOVÁ, D. (2012). Cytotoxicita vybraných aminoglykozidových a makrolidových antibiotík v bunkách živočíchov. Dizertačná práca, 2012, SPU Nitra.

GIGUÈRE, S. - PRESCOTT, J. F. - DOWLING, M. P. (2013). Antimicrobial Therapy in Veterinary Medicine, Fifth Edition. Iowa : Wiley Blackwell, 683 p. ISBN: 978-0-470-96302-9. http://dx.doi.org/10.1002/9781118675014.ch18 GLORIA, A. - CONTRI, A. - WEGHER, L. - VIGNOLA, G. DELlAMARIA, D. - CARLUCCIO, A. (2014). The effects of antibiotic additions to extenders on fresh andfrozen-thawed bull semen. Animal

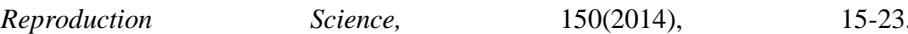
http://dx.doi.org/10.1016/j.anireprosci.2014.08.012

GONZALEZ-MARIN, C. - KJELLAND, M. E. - ROY, R. - LOPEZFERNANDEZ, C. - FERNANDEZ, J. L. - MORENO, J. F. - GOSALVEZ, J. (2012). Use of quinolones in bull semen extenders to reduce sperm deoxyribonucleic acid damage. American Journal of Animal and Veterinary Sciences, 7(4), 180-185. http://dx.doi.org/10.3844/ajavsp.2012.180.185

HOGEVEEN, H. 2005. Mastitis in dairy production. The Netherlands Wageningen Academic Publishers, 744 p. ISBN: 978-90-76998-70-1. DOI: http://dx.doi.org/10.3920/978-90-8686-550-5

MADAIRA, E. M. - GOULARTE, K. L. - FRADIEÉ, J. - MONDADORI, R. G. - LUCIA, T. - BIANCHI, I. - VIEIRA, A. D. - LEITE, F. P. L. (2014). The Use of Antibiotics in Cryopreservation of Ram Sperm. International Journal of Veterinary Medicine: Research \& Reports, 2014(2014) Article ID 154947, 7 pages. http://dx.doi.org/10.5171/2014.154947

MAROTO MARTÍN, L.O., CRUZ MU`NOZ, E., DE CUPERE, F., VAN DRIESSCHE, E.,ECHEMENDIA-BLANCO, D., MACHADO RODRÍGUEZ, J.M., BEECKMANS, S. (2010). Bacterial contamination of boar semen affects the litter size. Animal Reproduction Science, 120(1-4), 95-104. http://dx.doi.org/10.1016/j.anireprosci.2010.03.008

MASSÁNYI, P. - CHRENEK, P. - LUKÁČ, N. - MAKAREVICH, A. V. OSTRO, A. - ŽIVČAK, J. - BULLA, J. (2008). Comparison of different evaluation chambers for analysis of rabbit spermatozoa motility parameters using CASA system. Slovak Journal of Animal Science, 41(2), 60-66.

MORRELL, J. M. (2006). Update on semen technologies for animal breeding. Reproduction in domestic animals, 41(1), 63-67. http://dx.doi.org/10.1111/j.1439-0531.2006.00621.x

PLUMB, D. C. (2008). Plumb's Veterinary Drug Handbook, Sixth Edition. Iowa : Wiley Blackwell, 1136 p. ISBN: 978-0-8138-1097-3.

QADEERA, S. - BATOOLA, A. - MEHBOOBA, K. - ANSARIB, M. S. RAKHAA, B. A. - ANDRABIC, S. M. H. - ULLAHD, N. - IQBALB, R. AKHTERA, S. (2013). Comparison of traditional antibiotic streptomycin with neomycin, polymyxin B, or colistin in extender for buffalo (Bubalus bubalis) bull spermatozoa. Journal of Applied Animal Research, 41(3), 289-293. http://dx.doi.org/10.1080/09712119.2013.782866

REICKS, D. L. - LEVIS, D. G. (2008). Fertility of semen used in commercial production and the impact of sperm numbers and bacterial counts. Theriogenology, $70(8)$

http://dx.doi.org/10.1016/j.theriogenology.2008.07.019

SÁRKÖZY, G. (2001). Quinolones: A class of antimicrobial agents. Veterinarni Medicina, 46(9), 257-274.

SCHULZE, M. - DATHE, M. - WABERSKI, D. - MÜLLER, K. (2016). Liquid storage of boar semen: Current and future perspectives on the use of cationic antimicrobial peptides to replace antibiotics in semen extenders. Theriogenology, 85(2016), 39-46. http://dx.doi.org/10.1016/j.theriogenology.2015.07.016

SUAREZ, S. S. - PACEY, A. A. (2006). Sperm transport in the female reproductive tract. Human Reproduction Update, 12(1), 23-37. http://dx.doi.org/10.1093/humupd/dmi047

THIBIER, M. - GUERIN, B. (2000). Hygienic aspects of storage and use of semen for artificial insemination. Animal Reproduction Science, 62(1-3), 233 251. http://dx.doi.org/10.1016/s0378-4320(00)00161-5

TVRDÁ, E. - LUKÁČ, N. - JAMBOR, T. - LUKÁČOVÁ, J. - MASSÁNYI, P. 2015. Curcumin in male fertility: Effect on spermatozoa vitality and oxidative balance. Journal of Microbiology, Biotechnology and Food Sciences, 4(special issue2), 120-124. http://dx.doi.org/10.15414/jmbfs.2015.4.special2.120-124

WHO Technical Report Series, no. 954, 2009. Evaluation of certain veterinary drug residues in food. Seventieth report of the Joint FAO/WHO Expert 
Committee on Food Additives. Geneva, 21-29 October 2008, 134 p. ISBN 97892 41209540.

YÁNIZ, J. L. - MARCO-AGUADO, M. A. - MATEOS, J. A. - SANTOLARIA,

P. (2010). Bacterial contamination of ram semen, antibiotic sensitivities and effects on sperm quality during storage at $15^{\circ} \mathrm{C}$. Animal Reproduction Science, 122(1-2), 142-149. http://dx.doi.org/10.1016/j.anireprosci.2010.08.006 